\title{
The Influence of Instrumental Music and Relaxation towards Information Retrieval on Students
}

\author{
Tatik Imadatus Sa'adati \\ Kediri State Islamic Institute \\ imakediri@gmail.com
}

\begin{abstract}
The learning process requires information processing which consists of encoding (receiving information), storage (saving information) and retrieval (restoration of information that has been saved) in order to develop the method of learning that is supported by the approach of music art. The present research combines instrumental music with relaxation to help student prepare for learning. The purpose of this research is to determine the effect of instrumental music use and relaxation towards the ability to recall information (retrieval) on students of Kediri State Islamic Institute (STAIN Kediri). This research uses quasi experimental research method with non-randomized pretest-posttest control group design. The independent variable is instrumental and relaxation music, the dependent variable is the retrieval, and the control variable is the students of STAIN Kediri. The music used is Motivator and Energizer and the type of relaxation used is Autogenic Relaxation. The subjects of the study comprises of 20 students included in the control group and 30 students in the treatment group. The data analysis used one-sample t-test, with 0.000 significance result, which indicated that instrumental and relaxation music had a significant effect on the ability to recall information (retrieval) on STAIN Kediri students.
\end{abstract}

Keywords: Instrumental music, relaxation, retrieval.

\section{INTRODUCTION}

The process of sharpening memory ability is in the human body and part of the brain. Afin (2013) suggests that the brain is used for learning, in contrast to learning the brain's ability can also be improved. One of the learning processes is information processing which consists of encoding (receiving information), storage (saving information) and retrieval (restoration of what has been saved). In the realm of education, learning achievement can be measured by several tests presented in some forms, where the point is that the process of reminders is absolutely necessary. This is reinforced by the theory of the test as a form of learning written by Vered and Robert (2011) who states that there are two advantages of using test as to compare the results of the first resolutions of the retrieval hypothesis (including how the effort involved in remembering and how the process improves memory), and the second is the desired level of difficulty of the test (creating different learning strategies that can improve the ability to remember from the initial understanding).

Sutanto (2012) asserted that the instrumental music in the learning process will affect the performance of brain waves, which will maximize the ability of individuals to absorb information. The pattern of brain waves determines the mental state while brain waves determine the state of mind. As a basic information that the brain consists of billions of brain cells called neurons. Each neuron communicates with an electric wave. These waves are released by neurons in the brain called brainwaves. Waves in the brain are classified into delta waves, theta, alpha and beta. Each wave has different characteristics and signifies a person's mental state.
According to Adi (2003), music is processed by auditory cortex in the form of sound. Then we can enjoy the music with our right brain. While the left brain will process the lyrics contained in the music or song. The next effect is on our limbic or mammalian brain system. In addition to handling long-term memory, the limbic system also handles responses to music and emotions. That is why learning by using the right music will greatly help improving memory. When we listen to music to accompany learning process, our left brain is also learning as well as our right brain does its job to enjoy music. This simultaneous stimulation between the left brain and the right brain is what we know by the term whole-brain learning or learning with the whole. Reinforced by Kalat (2010) which suggested that every cell in the main auditory cortex provides the best response for tones of different frequencies, although many cells respond better to complex tones than single-frequency tones. The cells in the auditory cortex provide the strongest response to the sounds that interest us, such as strange sounds and rich harmonization sounds and areas that restrict the main auditory cortex to analyze the meaning of sound.

Information retrieval is a process of recalling all the information we have stored in the brain when necessary. This mechanism is very helpful in everyday life. There are three types of processes, according to Hilgart quoted by Annie (2013), namely, 1) Recall, which is to recall information learned on past without any clue, 2) Recognition, which is to recall an information that has been previously learned by someone. Thus, one can remember because there are clues that can help to remember the information from his brain, and 3) Redintegrative, the process of recalling a necessary information by reconciling the 
existing information into a concept or a fairly complex story.

In the present study, the relaxation process is also given. A review from a biological point of view by Taufik (2008) which states that the relaxation response takes place through a meaningful decrease of the acidic (oxygen) requirement by the body. The body becomes relaxed because it works lightly. The metabolism diminishes, the exchange of "life" components takes place in an atmosphere of insecurity. It is also asserted that when body reacts (in the form of relaxation), the brain reveals alpha waves, which means the brain is clear, relaxed, yet alert in performing something. The brain is in an "incubation" stage that becomes the entrance for the subconscious force. Hence, the alpha state triggered by the relaxation reaction of the body will reveal human subconscious information at about $88 \%$. Relaxation done in any way will make the body become calm. In reciprocity, it affects the metabolism and blood flow of the body. Therefore, the relaxed state of the body can make a person in a healthy condition, and in principle, the body can streamline its oxygen use. If the brain is relaxed, the brain does not demand much oxygen.

The psychological perspective of relaxation explained by Bernstein and Borkovec in Richard (2011) emphasizes the importance of the focus-tenserelease-relax cycle in relaxation. This relaxed stretching cycle has five elements: (a) focus, focusing attention on a particular muscle group, (b) tense, stretching the muscle group, (c) hold, holding that tension for five to seven seconds; (d) release, releasing the tension within the muscle group; and (e) relax, focusing attention on releasing further tension and relaxation in the muscle group.

In practical level, the researcher wants to examine whether there is influence of relaxation and instrumental music toward the retrieval ability in students at STAIN Kediri. From several short interviews prior to the present research, it is well known that lecture time during the day becomes one of the factors that reduce the students' motivation to learn. Students become unprepared, saturated, lazy and difficult to understand the material, of course, it implies the decline in the ability to process information and decrease the understanding of information. Based on these conditions, there is an effort to make the students motivated again to follow the daytime lecture for seventh grade students or more (at 12:30 onwards) with one experimental test method using instrumental music that is played 30 minutes before the lecture begins. Along with the experiments, researcher assume that students can utilize the time for relaxation and instrumental music so that the brain will be ready to receive material and information. Basically this instrumental music will affect the calm (relax) students which further affect the brain waves that are ready to receive the class material. Therefore, several descriptions above become the basis of the researcher's interest to elaborate in a study entitled "The Influence of Instrumental and Relaxation toward the Ability to recall information (Retrieval) on students of STAIN Kediri.

\section{METHOD}

Referring to the theory of research methodology by Latipun (2012), the present research used experimental method, which is basically a quantitative research. The experimental design used was called quasi experimental (with non-randomized pretest-posttest control group design). The purpose of this study was to describe and compare the value of retrieval skills on students of STAIN Kediri who were made as control group or group that had been given treatment (treatment group).

The sample in this research were 50 students of STAIN Kediri, consisting of 20 students of Communication Studies of Islamic Broadcasting, Ushuluddin Department and Social Sciences as the control group, and 30 students from Tafsir Hadist Program of Ushuluddin Department and Social Sciences as the treatment group. The sample selection is based on a reference from Sugiyono (2012), who wrote that the number of samples in a simple experimental study, using experimental groups and control groups, then the number of sample members each between 10-20 people.

The sampling technique for this research uses nonrandom technique. Referring to Sugiono (2012), the researcher assigned a sample of 50 students after several observations on several class lectures, some considerations of time, place and lecturer as well as department of Tafsir Hadist and department of Communication of Islamic Broadcasting which are under Department of Ushuluddin and Social Science at STAIN Kediri. Characteristics of students that can be used research is: (1) because this research is an experiment, then the class that will be used for research is at least 15 students, (2) students who joined the schedule of 7 th lecture of the day (12.30-14.10 GMT+7) and previously had a lecture since morning, and (3) lecturer who has teaching schedule since morning.

The process of collecting data in this study is divided into several stages, namely, (1) Conducting observations in several classes and asking about the duration of lectures (including students who are involved in the schedule of 12.30-14.10 GMT+7); (2) Determining classes that comprise of 2 classes, consisting of 20 first-semester students of Islamic Communication Department in Civic Education subject as the control group (first class), and 30 firstsemester students of Tafsir Hadist Department in Basic Cultural and Social Sciences (ISBD) subject as the treatment group (second class), (3) Conducting pretest in the control group, (4) Conducting pretest on the treatment group, (5) Conducting posttest on the control group, and (6) Conducting posttest on the treatment group in the laboratory of Psychology of STAIN Kediri. 
The process in giving treatment to the subject is described as follows: at 12.30 students entered the class. Researcher and the research assistants sought approval on students who would undergo instrumental and relaxation music sessions, the researchers provided simple relaxation exercises (relaxation of breath and muscle), students are required to learn to breathe properly and be informed of the instrumental and relaxation procedures. After the students understood, they were asked to take a comfortable sitting position, the room lights were turned off, then researchers played music "Motivator \& Energizer - Binaural Beat.wav" for 30.51 seconds of rotation and duration, along with the relaxation. Researcher and research assistants observed students through CCTV in the student room. After 30 minutes and the music finished, the room lights were turned on again and the lecture began, and then 15 minutes prior to the last session in the class, the lecturer gave 10 questions to the students. The questions deal with how to grant the problem with the process look up or lecturers provide questions orally and directly answered by students in every number. In addition to the questionnaire, the researcher also provide feedback about the treatment consisting of 4 numbers to be filled by the students. After that, the answer sheets and feedback were collected by the research assistant and was ended by thanking the students for their cooperation.

Tabel 01. Descriptive Statistics

\begin{tabular}{|c|c|c|c|c|c|c|c|c|}
\hline & & & $\begin{array}{l}\text { Minim } \\
\text { um }\end{array}$ & $\begin{array}{l}\text { Maxi } \\
\text { mum }\end{array}$ & Sum & $\begin{array}{l}\text { Mea } \\
\mathrm{n}\end{array}$ & $\begin{array}{l}\text { Std. } \\
\text { Devia } \\
\text { tion }\end{array}$ & Variance \\
\hline $\begin{array}{l}\text { Pretest } \\
\text { kel.perlakuan }\end{array}$ & & 30 & 4 & 10 & 214 & 7.13 & 1.548 & 2.395 \\
\hline \multicolumn{2}{|l|}{$\begin{array}{l}\text { Posttest } \\
\text { kel.perlakuan }\end{array}$} & 30 & 5 & 10 & 263 & 8.77 & 1.165 & 1.357 \\
\hline $\begin{array}{l}\text { Pretest } \\
\text { Control }\end{array}$ & kel. & 20 & 2 & 10 & 142 & 7.10 & 2.150 & 4.621 \\
\hline $\begin{array}{l}\text { Posttest } \\
\text { Control }\end{array}$ & kel. & 20 & 2 & 10 & 142 & 7.10 & 2.936 & 8.621 \\
\hline Valid N (listw & ise) & 20 & & & & & & \\
\hline
\end{tabular}

This study uses instruments in the form of questions that are used to evaluate and measure the ability of retrieval which is also included in the category of achievement test as the primary data. Based on the class' material, lecture made the problems consisting of 10 numbers with a completion duration of approximately 10 minutes. The questions comprise of: (1) Pretest in Civic Education subject with the subchapter of Nature and Values of Pancasila in the control group, (2) Pretest for ISBD subject with the subchapters of Human as Individual and Social Beings (in the treatment group, (3) Posttest for Civic Education subjects with the National Identity chapters (in the control group), (5) Posttest of ISBD subject with the sub-chapters of Human and Civilization (in the treatment group). The purpose of pretest and posttest is to know the basic ability of the students before being given treatment, in addition to test whether the two groups are homogeneous, so the results of the two scores can be compared. The scoring of assessment is presented as 1 and 0 . If the answer is true, each number is given a score of 1 (maximum score 10), as well as the score of 0 (minimum value 0 ) when the answer is incorrect.

The variables in this study are: (1) Relaxation with instrumental music as the independent variable; (2) Retrieval as the dependent variable; and (3) Control variables include registered students at STAIN Kediri, the lecturer (same lecturer for 2 groups), experimental place (Laboratory of Psychology STAIN Kediri), schedule of the research (12.30-14.10 GMT+7), physical condition of lecturers and students (both have been doing activities since morning), and the material taught were in one area of social science.

\section{ANALYSIS AND RESULT}

Kolmogorov-Smirnov test was used in the normality test on the pretest from control group and treatment group. It was found that pretest value of the control group had significance equal to 0,526 while in the treatment group equal to 0,368 because the significance is above 0.05 then both data are considered as normal distribution.

The homogeneity test in the control and treatment group showed the significance value of the control group 0.370 and the treatment group of 0.927 . It is also because the significance value is above 0.05 then both data are considered homogeneous.

Normality test on posttest data from control group and treatment group had significance result $(0.000)$ in the control group, and 0,458 in the treatment group. Because the control group's significance was less than 0,05 then data was not normally distributed, and control group significance was above 0,05 . This means that the data is normally distributed.

One-Sample Test

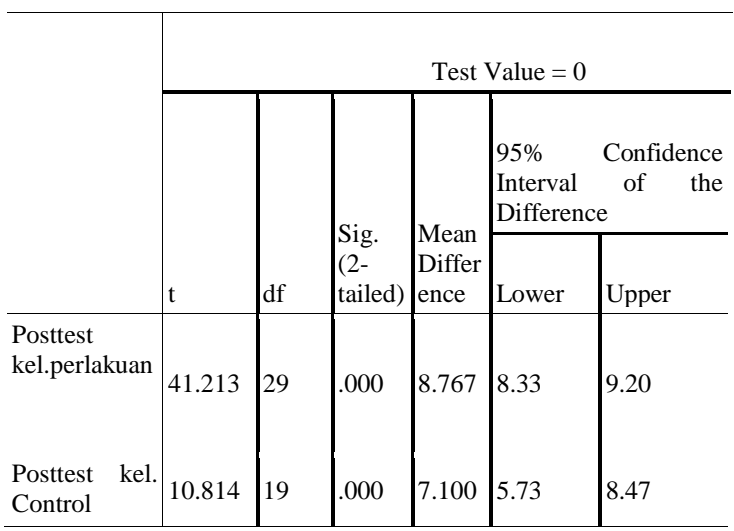

Homogeneity test of posttest in the control group and treatment group showed significance value of control group of 0,141 and in the treatment group of 0,726 . Because the significance value is above 0.05 then both data are considered homogeneous. With the help of SPSS 16.0 for Windows software, the data is analyzed and the result of overall data descriptions can be seen as follow table 01 . 
Table 02 Hypothesis Test. One-Sample Statistics

\begin{tabular}{lllll} 
& & & $\begin{array}{l}\text { Std. } \\
\text { Deviation }\end{array}$ & $\begin{array}{l}\text { Std. Error } \\
\text { Mean }\end{array}$ \\
\hline Posttest kel.perlakuan & & & & \\
& 30 & 8.77 & 1.165 & .213
\end{tabular}

Posttest kel. Control

$20 \quad 7.10 \quad 2.936$

Based on the table above, the control and treatment groups had approximately the same average at the pretest and after treatment. The mean was 8.7 and the control group was still the same. This means there is significant result from instrumental and music relaxation to the students.

From the previous table, it can be seen that the data is homogeneous (same variance), and from the table above can be seen sig. (2-tailed) 0,000. Since the significance of the $t$ test is less than 0.05 then Ho is

rejected and means $\mathrm{Ha}$ is accepted, we can conclude that there is a significant difference in retrieval ability between the group which is exposed to instrumental and relaxation (treated group) and group which is not (untreated group).

\section{DISCUSSION}

Based on the data analysis, the proposed hypothesis is accepted, or in other words that the giving of instrumental and relaxation music to the students has an effect on students' retrieval ability. Thus, we can try an alternative new learning model with music.

Overall there is a striking average difference. The non-treated groups had the same average of pretest and posttest, but the treatment-treated groups showed an average rise of 1.57 points (from 7.13 to 8.7 ) and this made the researcher sure that on certain subjects, instrumental music and relaxation will affect the ability of retrieval on students.

During the research, researcher looked at the enthusiasm and good cooperation of the students. Most of them had never been introduced to such methods and were quite fond of this technique. However, what they might need to look for is music with a shorter span of time so they do not spend too much time on lectures. Some of the students felt it was important to occasionally be exposed to this kind of treatment.

This study attempts to examine and relate some matters relating to information processing. As described in the previous chapter, there is a systematic demarcation between retrieval that begins with the encoding process (information in the brain). What we need to underline is that the encoding process in human beings is influenced by internal and external factors. External factors deals with the environment that must be conducive and can affect mood or human feelings. When associated with learning, a pleasant learning environment will affect the learning outcomes.

The link between music, learning, and the brain can be explored from an article written by Ratna (2010). She affirms that research on the brain is a lot to do with things, one of them is with music and learning. Some studies use music to influence the brain to improve concentration and learning. Music has a powerful effect on the learning environment. Research shows that learning is easier and faster if learners are relaxed and receptive. Generally, the heart rate of people in this state is 60 to 80 times per minute. In this state the brain enters an alpha wave $(8-12 \mathrm{~Hz})$, which is a relaxed state but alert state of the brain so that parts of the brain, the hippocampus and somatosensory, can work optimally. Music has an effect on brain electrophysiology and has been reported in many studies.

There are several experimental studies conducted at various levels of education with varying results. Joints and Lastri (2016) perform a measurement on the students' ability of Faculty of Psychology Padjadjaran University in understanding journal. The calculation result with the t-test difference shows that the value of 1,956 which is higher than the value in the t distribution table $(1,701)$. Thus, it can be concluded that there is an effect of Kitaro Instrumental Music on the major tone to the improvement of reading comprehension on journal although the resulting increase is not significant. This is due to the ability of reading comprehension as one of the complex cognitive functions, not the aspect that can be increased significantly in a short time, however, the treatment is done only once. In this case, it takes a certain time a process as well as the treatment should be done continuously.

Music relaxation can be applied to improve students' achievement of primary school. Research conducted by Wahyu (2014) shows that there is an influence of instrumental music media on the skills of writing poetry of fifth grade of State Secondary School of Ketintang I / 409 Surabaya. The results of the study showed that the learning by using instrumental music media is very good to support the learning activities of writing poetry. Instrumental music media will help students in delivering ideas in poetry.

Instrumental music can also be useful for decreasing anxiety. The supporting research was done by Devi and Varidah (2011) on 14 students of State Senior High School 5 Yogyakarta of social science (IPS) specialization. The subjects were second grade students who have above average IQ score and very high anxiety level. Results of the study showed a significant decrease in scores between pretest and posttest on experimental group with $\mathrm{p}=0.014$ which indicate that classical music reduces mathematical anxiety in students. Math anxiety may also decreased as students listen to classical music while learning math.

Learning durability can also be affected by relaxation music. This conclusion from the results of research conducted by Saifaturrahmi and Anggia (2011). They describe the data in the form of gaining score between pretest-posttest which shows a significant difference before and after given the treatment. The experimental group gain score (2.75) which is higher than the control group (0.5) with a value of 3,100 $t$ value is greater than the value of $t$ table 2,145 . This means that classical music can increase the concentration of students in learning. Similar research 
is also conducted by Jacko (2016) which aims to determine empirically the influence of classical music on the concentration of learning. The subjects used in this study are students of Catholic University of Soegijapranata Semarang in several faculties, namely, faculty of agricultural technology, faculty of psychology, faculty of architecture and design, faculty of law and communication, and faculty of economics and business. The subjects were 18 people whose age ranged between 18-22 years. The results of analysis were obtained by using t-test, with mean result before being given treatment (without music) showed 67.56 and after treatment (with music) mean increased to 75.33. The calculation result in experiment group showed significance value less than 0.05 ie 0.012 . While in the control group showed a level of significance greater than 0.05 that equals to 0.672 . The results of this calculation indicate that there is a significant effect of music on the concentration of learning.

Interesting insight appear when researcher discusses with Islamic scholar that came the idea of developing research that is more islamic by using instrumental music. Procedures that may be performed are instrumental music played on the individual while relaxation. For instance, when breathing in, one gives positive suggestions to the brain, for example reciting Asmaul Husna, dhikr, or reading other Islamic prayers. Then the students will breathe out slowly. This insight triggers researcher because according to Taufik (2008), there is a law "incident" in our brain that the brain never distinguishes what happens, dreams, and imagination. All these events are real. This means that our brain responds to everytime we think, and if we are able to make the relaxation for the brain to be more calm, then the way we think will also be more calm. Thus, when the mind is calm, we can easily understand particular things.

Overall, there are some findings of this study, namely: (1) there is a significant result in the ability of inter-retrieval students who were treated and those who were not. (2) the method is a new method in the educational institution, and (3) students respond positively to the method. Thus, the results of this study are expected to contribute innovation in terms of classroom learning methods to help students improve their academic achievement.

\section{REFERENCES}

Adi W. Gunawan, (2003). Genius Learning Strategy: Petunjuk praktis untuk menerapkan Accelerated Learning. Jakarta: Gramedia.

Afin Murtie, (2013). Melatih Otak Anti-Lupa Dengan Metode Laci Pikiran : bagaimana cara menyimpan memori-memori yang diperlukan dalam otak dan membukanya kembali pada saat dibutuhkan. Yogyakarta: Media Pressindo.

Andreas Robin Jacko. (2016) Pengaruh Musik Klasik Terhadap Konsentrasi Belajar. Thesis Unika Soegijapranata.. Ditemukan Kembali Pada $\begin{array}{lllll}\text { Tanggal } & 24 & \text { Juli } & 2017 & \text { dari }\end{array}$ http://repository.unika.ac.id/13143/
Devi Winja Susanti \& Faridah Ainur Rohmah, (2011). Efektivitas Musik Klasik Dalam Menurunkankecemasan Matematika (Math Anxiety)Pada Siswa Kelas Xi Jurnal Humanitas, Vol. VIII No.2 Agustus 2011, Fakultas Psikologi Universitas Ahmad Dahlan, Yogyakarta. Ditemukan kembali pada tanggal 24 Juli 2017 dari file:///C:/Users/user/Downloads/460-576-1PB.pdf.

J.W Kalat, (2010) . Biopsikologi, Buku 1, Edisi 9. Jakarta : Salemba Humaika

Latipun. (2002). Psikologi Eksperimen. (Malang : UMM Press)

Ratna Supradewi, (2010).Otak, Musik, Dan Proses Belajar, Buletin Psikologi Fakultas Psikologi Universitas Gadjah MadaVolume 18, No. 2, 2010: 58 - 68 Issn: 0854-7108. Ditemukan kembali pada tanggal $24 \quad$ Juli 2017 darihttps://jurnal.ugm.ac.id/buletinpsikologi/arti cle/viewFile/11538/8604

Richard Nelson-Jones. (2011). Teori dan Praktik Konseling dan Terapi, edisi kempat. Yogyakarta : Pustaka Pelajar.

Saifaturrahmi Hidayat Dan Anggia Kargenti Evanurul Marettih. (2011).Pengaruh Musik Klasik Terhadap Daya Tahan Konsentrasi Dalam Belajar. Jurnal Psikologi No. 2 / Vol.7 / December 2011 Fakultas Psikologi Universitas Islam Negeri Sultan Syarif Kasim Riau. Ditemukan Kembali Pada Tanggal 24 Juli 2017 dari

http://library.gunadarma.ac.id/journal/view/791 1/pengaruh-musik-klasik-terhadap-daya-tahankonsentrasi-dalam-belajar.html/

Sendi Etika Andini, Lastri Yeni Indra, M. Biyan Raka. (2016). Pengaruh Pemberian Musik Instrumental Kitaro Pada Nada Mayor Terhadap Peningkatan Kemampuan ReadingComprehension Jurnal. Skripsi. Ditemukan Kembali Pada Tanggal 24 Juli 2017 darihttp://pustaka.unpad.ac.id/wpcontent/uploads/2016/10/Sendi-EtikaAndini.pdf

Sugiyono. (2012). Metode Penelitian Kombinasi (mixed Methods). Bandung : Alfabeta

Sutanto Windura. (2012) Brain Management Series: 88 Cemilan Otak Sehat 88 Buku cemilan otak.Jakarta: Gramedia

Taufiq Pasiak. (2008). Revolusi IQ/EQ/SQ Menyingkap Rahasia Kecerdasan Berdasarkan Al-Quran dan Neurosisme Mutakhir. Bandung : Mizan Pustaka.

Tim terapi musik, "Mengenal CD Terapi Musik”, Ditemukan kembali pada tanggal 24 Juli 2017 dari http://www.terapimusik.com/terapi_musik.htm

Vered Halamish \& Robert A. Bjork, (2011). "When Does Testing Enhance Retention?: A DistributionBased Interpretation of retrieval as a Memory Modifier”, Journal of Experimental Psychology : Learning, memory and Cognition. American psychological Association vol 37,801-812. Ditemukan kembalipada tanggal 24 Juli 2017 darihttps://bjorklab.psych.ucla.edu/wpcontent/u ploads/sites/13/2016/07/Halamish RBjork 201 $1 . p d f$. 